\title{
Kajian Potensi Perkebunan Rakyat di Provinsi Sumatera Utara Menggunakan Location Quotient dan Shift Share
}

\author{
Rita Herawaty Br Bangun \\ Fungsional Statistisi Badan Pusat Statistik (BPS) Provinsi Sumatera Utara \\ Email:rbangun62@gmail.com
}

\begin{abstract}
Abstrak
Kajian ini bertujuan untuk mengidentifikasi distribusi sektor-sektor perkebunan rakyat di Provinsi Sumatera Utara. Metode yang digunakan dalam kajian ini adalah analisis location quetiont (LQ) dan analisis shift share. Hasil kajian menunjukkan bahwa komoditas yang menjadi unggulan/basis Provinsi Sumatera Utara adalah kelapa sawit. Sedangkan komoditas yang menunjukkan pertumbuhan yang signifikan antara tahun 2011-2015 adalah karet, kopi, coklat, cengkeh, tembakau, pala, lada, kapuk dan panili. Analisis differrential shift menunjukkan bahwa karet, kopi, kelapa sawit, coklat,cengkeh, kulit manis, kemiri, tembakau, tebu, pala, lada, kapuk, pinang dan vanili mempunyai pertumbuhan yang lebih cepat dan memiliki daya saing yang tinggi.
\end{abstract}

Kata kunci : perkebunan rakyat, location quotient, shift share.

\begin{abstract}
Objective of this study was identification of competitive commodities smallholder estate crops in province of Sumatera Utara. The methods were used location quetiont (LQ) and shift share analysis. The result of this study shows that the base of this product was oil palm. Furthermore, the products shows increase significantly about 2011-2015 were rubber, coffee, cacao, clove, tobacco, nutmeg, pepper, kapok, and vanilla. Differential shift analysis shows that rubber, coffee, oil palm, cacao, clove, cinnamon, candlenut, tobacco, sugar cane, nutmeg, kapok, areca nut, and vanilla had rapid develop and higher competitiveness.
\end{abstract}

Keywords : smallholder crops, location quotient, shift share.

\section{PENDAHULUAN}

Pembangunan bidang pertanian perlahan mulai bergeser dari pertanian tanaman pangan mengarah ke tanaman perkebunan unggulan yang mendukung agroindustri, seperti kelapa sawit dan karet. Beberapa alasan peralihan paradigma tersebut disebabkan agroindustri, terutama komoditas perkebunan, merupakan sarana meningkatkan nilai tambah, membuka lapangan kerja, memperluas pasar bagi produk pertanian dan menunjang usaha peningkatan pendapatan serta kesejahteraan petani. Salah satu karakteristik agroindustry adalah arah strategi pengembangannya harus didasarkan pada pendekatan wilayah potensi sumberdaya dengan tetap berpijak pada konsep keunggulan komparatif (Rahmad Hidayat, 2013). Oleh sebab itu, sentuhan kebijakan bagi pengembangan pembangunan pertanian wilayah khususnya sektor perkebunan, masih sangat diperlukan untuk meningkatkan kesejahteraan masyarakat petani (Rahmad Hidayat, 2013). 
Sektor pertanian di Sumatera Utara, memberikan kontribusi terbesar terhadap Produk Domestik Regional Bruto (PDRB) sebesar 22,01 persen pada tahun 2015 dibanding dengan sektor yang lain. Sektor ini menjadi andalan dalam penyerapan tenaga kerja di Sumatera Utara sebanyak 41,30 persen. Data tersebut berdasarkan hasil Survei Angkatan Kerja Nasional (Sakernas) 2015 yang dilakukan oleh Badan Pusat Statistik Provinsi Sumatera Utara (2016). Salah satu sub sektor pertanian yang mempunyai peranan penting dalam pembangunan pertanian adalah sub sektor perkebunan. Peranan penting sub sektor perkebunan antara lain sebagai penyedia bahan baku untuk sektor industri, penyerap tenaga kerja, dan peyumbang devisa. Sub sektor perkebunan mempunyai kontribusi dalam PDRB sebesar 44,73 persen dari total PDRB sektor pertanian (BPS, 2016a).

Besarnya kontribusi PDRB sub sektor perkebunan rakyat didukung oleh potensi lahan yang ada di Provinsi Sumatera Utara. Potensi lahan perkebunan di Provinsi Sumatera Utara seluas 1,08 juta hektar (BPS, 2016b). Komoditas perkebunan yang diusahakan oleh petani didominasi perkebunan karet, kelapa sawit, kopi, dan kelapa. Luas lahan komoditi perkebuanan berturut-turut adalah karet sebesar 36,41 persen, lahan kelapa sawit sebesar 36,34 persen, lahan kelapa sebesar 7,83 persen, dan lahan kopi sebesar 7,48 persen. Selama kurun waktu 2012-2015, luas lahan yang disuahakan dan produksi perkebunan cenderung meningkat terutama komoditas karet dan kelapa sawit. Hal ini mengindikasikan bahwa minat petani untuk mengusahakan komoditas perkebunan semakin tinggi.

Berdasarkan hal di atas perlu dibuat kajian untuk menganalisis komoditas unggulan sub sektor perkebunan dan menganalisis struktur dan laju pertumbuhan produksi komoditas perkebunan di Provinsi Sumatera. Salah satu metode yang dapat digunakan untuk menganalisis adalah analisis Location Quotient (LQ). Analisis LQ merupakan suatu metode untuk mengetahui potensi sektor/komoditas merupakan komoditas basis atau non basis pada bidang pertanian (Wahyuningsih et al., 2014 ; Kristiawan et al., 2016). Tujuan dari kajian ini adalah mengidentifikasi distribusi sektor-sektor perkebunan rakyat di provinsi Sumatera Utara. Hasil kajian ini diharapkan dapat dijadikan acuan dalam peningkatan kesejahteraan masyarakat khususnya petani dan mendorong terciptanya agroindustri yang mendorong perekonomian masyarakat.

\section{METODOLOGI PENELITIAN}

Data yang digunakan dalam kajian ini adalah data sekunder. Data diperoleh dari Badan Pusat Statistik Provinsi Sumatera Utara dan Dinas Perkebunan Provinsi Sumatera Utara. Data tersebut adalah data produksi komoditas perkebunan tahun 2011 sampai dengan tahun 2015.

Metode analisis data yang digunakan dalam kajian ini adalah analisis kuantitatif yang digunakan untuk mempermudah analisis tabeltabel dan grafik secara sederhana sehingga didapatkan gambaran mengenai perkembangan dari objek penelitian. Untuk menjawab permasalahan yang telah ditetapkan, maka digunakan beberapa metode analisis data, yaitu analisis Location Quotient (LQ) dan analisis Shift Share.

LQ adalah suatu metode untuk menghitung perbandingan relatif sumbangan nilai tambah sebuah sektor di suatu daerah terhadap sumbangan nilai tambah sektor yang bersangkutan dalam skala provinsi atau nasional. Dengan kata lain, LQ dapat menghitung perbandingan antara share output sektor $i$ di kota/kabupaten dan share 
output sektor $i$ di provinsi. Nilai LQ akan memberikan indikasi kemampuan suatu daerah dalam menghasilkan suatu komoditas, apakah mempunyai potensi untuk mensupply daerah lain, mendatangkan dari daerah lain, atau dalam keadaan seimbang. Teknik LQ relevan juga digunakan sebagai metode untuk menentukan komoditas unggulan khususnya dari sisi penawaran (produksi atau populasi) (Hendayana, 2003). Secara matematis formula LQ adalah sebagai berikut :

$$
L Q_{i}=\frac{Y_{i j} / Y_{j}}{Y_{i} / Y}
$$

Keterangan:

$\mathrm{LQ}_{\mathrm{i}} \quad$ : Indeks Location Quetiont komoditas perkebunan i di Provinsi Sumatera Utara

$Y_{i j} \quad$ : Nilai produksi komoditas perkebunan i di Provinsi Sumatera Utara

$\mathrm{Y}_{\mathrm{j}} \quad$ : Total nilai produksi komoditas perkebunan di Provinsi Sumatera Utara

$\mathrm{Y}_{\mathrm{i}} \quad$ : Nilai produksi komoditi perkebunan i di Indonesia

Y : Nilai produksi total komoditi perkebunan di Indonesia

Kondisi analisis terbagi menjadi 3, yaitu:

LQ > 1 : artinya komoditas perkebunan tersebut merupakan komoditas perkebunan basis. Produksi komoditas perkebunan tersebut tidak hanya mampu memenuhi kebutuhan untuk wilayahnya namun dapat diekspor ke luar wilayah.

$\mathrm{LQ}=1:$ artinya komoditas perkebunan tersebut merupakan komoditas perkebunan non basis. Produksinya hanya cukup untuk memenuhi kebutuhan di dalam wilayah saja

$\mathrm{LQ}<1$ : artinya komoditas perkebunan tersebut merupakan komoditas non basis. Produksinya tidak dapat memenuhi kebutuhan wilayahnya sendiri sehingga perlu diimpor dari luar wilayah.

Analisis yang digunakan untuk melihat potensi ekonomi suatu wilayah. Menurut Mira (2016) metode shift share adalah analisis yang bertujuan untuk menentukan kinerja atau produktivitas kerja perekonomian daerah dengan membandingkannya dengan daerah yang lebih besar (regional atau nasional). Metode shift share memiliki analisis yang lebih tajam bila dibandingkan dengan analisis Location Quetiont (LQ) karena memberikan penjelasan secara terperinci penyebab perubahan atas beberapa variabel.

Menurut Suryani (2014) metode shift share memberikan data tentang kinerja perekonomian dalam 3 bidang yang berhubungan satu dengan yang lainnya yaitu:

a. Perubahan pengerjaan agregat secara sektoral dibandingkan dengan perubahan pada sektor yang sama di perekonomian yang dijadikan acuan.

b. Pergeseran (proporsional shift) mengukur perubahan relatif, pertumbuhan atau penurunan, pada daerah dibandingkan dengan perekonomian yang lebih besar yang dijadikan acuan. Pengukuran ini memungkinkan kita untuk mengetahui apakah perekonomian daerah terkonsentrasi pada sektorsektor yang tumbuh lebih cepat daripada perekonomian yang dijadikan acuan.

c. Pergeseran diferensial (differential shift) membantu kita dalam menentukan seberapa jauh daya saing sektor-sektor daerah (lokal) dengan perekomian yang dijadikan acuan. Oleh karena itu, jika pergeseran diferensial dari suatu sektor adalah positif, maka sektor tersebut lebih tinggi daya saingnya 
daripada sektor yang sama pada perekomian yang dijadikan acuan.

Menurut (Suryani,2014) bentuk umum persamaan dari analisis shift share dan komponen-komponennya adalah:

$$
\Delta E_{\mathrm{r},}=E_{\mathrm{r},},-\mathrm{E}_{r, \mathrm{i}, \mathrm{t}-\mathrm{n}}
$$

Artinya pertambahan lapangan kerja regional sektor i adalah jumlah lapangan kerja sektor i pada tahun akhir (t) dikurangkan dengan lapangan kerja sektor i pada tahun awal $(\mathrm{t}-\mathrm{n})$. Pertambahan lapangan kerja regional sektor i ini dapat diperinci atas pengaruh dari National share, Proportional share, dan Differential shift.

$$
\begin{aligned}
& \Delta E r_{,}=(N i+P i+D i) \\
& N i,=E,-n(E N, t / E N, t-n)-E r, i, t-n \\
& P i,=\{(E N, / E N, i, t-n)-(E N, t / E N, t-n)\} \times E r \\
& , i, t-n \\
& D i, t=\{E i, r, t-(E N, i, t) E N, i, t-n) E r, i, t-n\}
\end{aligned}
$$

Keterangan :

$\Delta \quad$ : Perubahan,tahun akhir (tahun $\mathrm{t}$ ) dikurangi dengan tahun awal (tahun t-n)

$\mathrm{N} \quad$ : Indonesia

$\mathrm{r}$ : Provinsi Sumatera Utara

E : Total Produksi Komoditas

Perkebunan

i : Sektor

$\mathrm{t} \quad$ : Tahun

$\mathrm{t}-\mathrm{n} \quad$ : Tahun awal

$\mathrm{Ni} \quad$ : National share

$\mathrm{Pi} \quad$ : Proportional shift

Di : Differential shift

Pengukuran dari analisis Shift Share (Suryani, 2016):

a. Ni bernilai positif, menunjukkan bahwa pertumbuhan sektor i di daerah lebih cepat dibanding dengan pertumbuhan sektor yang sama di daerah provinsi. Apabila $N i$ bernilai negatif, menunjukkan bahwa pertumbuhan sektor i di daerah lebih lambat dibanding dengan pertumbuhan sektor yang sama di daerah provinsi.

b. $P i$ menunjukkan komponen proportional shift yang dipakai untuk menghasilkan besarnya shift netto bila terjadi perubahan pada PDRB yang bersangkutan. Komponen ini positif di daerah yang berspesialisasi di sektor secara nasional tumbuh lebih cepat dan negatif bila daerah berspesialisasi pada sektor yang tumbuh lebih lambat.

c. Di menunjukkan differential shift yang dipakai untuk mengukur besarnya shift netto yang diakibatkan sektor tertentu yang lebih cepat atau lambat pertumbuhannya di daerah yang bersangkutan karena faktor lokasional seperti melimpahnya sumber daya dan mengukur keunggulan kompetitif sektor di daerah tersebut. $D i$ bernilai positif pada sektor yang memiliki keunggulan kompetitif dan $D i$ bernilai negatif pada sektor yang tidak memiliki keunggulan kompetitif.

\section{HASIL PEMBAHASAN}

Analisis Deskriptif

Provinsi Sumatera Utara merupakan salah satu daerah potensi perkebunan di Indonesia. Komoditas yang menjadi andalan adalah karet, kopi, kelapa sawit dan coklat. Secara umum perkembangan produksi komoditas perkebunan di Sumatera Utara dapat dilihat pada gambar 2 di bawah ini. Komoditas kelapa sawit selama 5 tahun menjadi komoditas perkebunan unggulan di Provinsi Sumatera Utara diikuti oleh karet dan kelapa. 


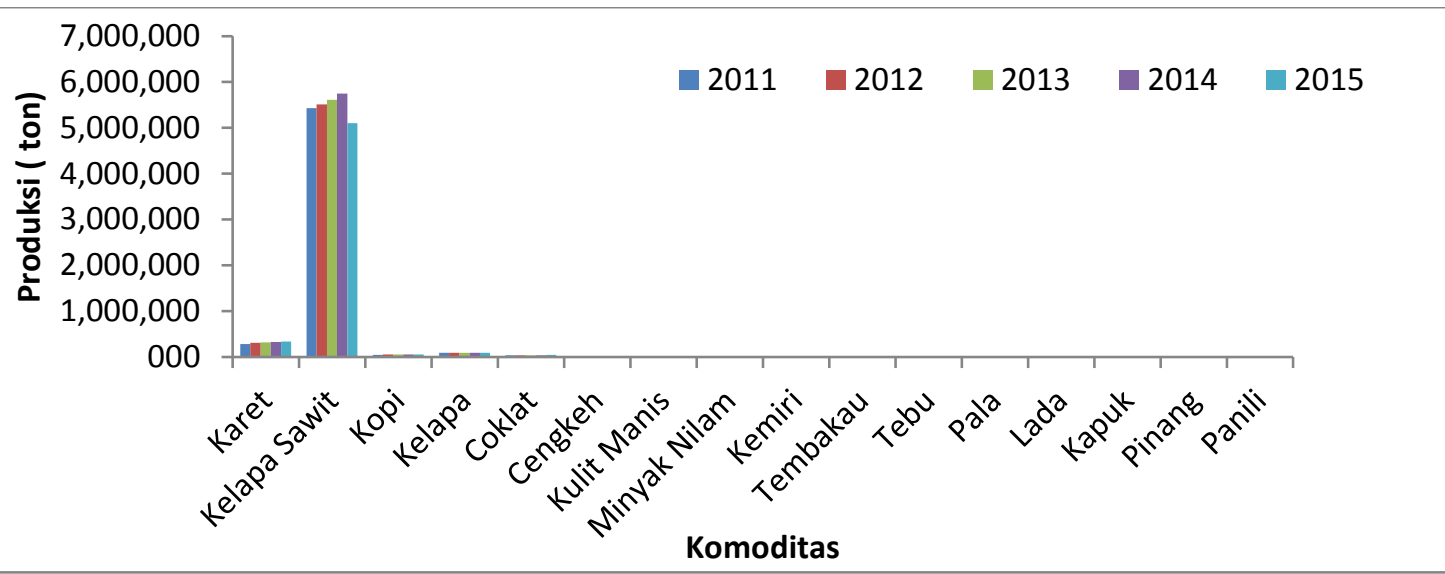

Gambar 2. Perkembangan produksi komoditas perkebunan di Sumatera Utara Tahun 2011-2015

Analisis Location Quetiont (LQ)

Hasil penghitungan Location

Quetiont (LQ) komoditas perkebunan di
Sumatera Utara dapat dilihat pada Tabel 1

Tabel 1. Hasil penghitungan Location Quetiont (LQ) komoditas perkebunan di Sumatera Utara Tahun 2011-2015

\begin{tabular}{lrrrrrrr}
\hline Komoditas & 2011 & 2012 & 2013 & 2014 & 2015 & $\begin{array}{r}\text { Rata- } \\
\text { rata }\end{array}$ & Kriteria \\
\hline Karet & 0,39 & 0,43 & 0,41 & 0,44 & 0,51 & 0,44 & NB \\
Kelapa Sawit & 1,68 & 1,67 & 1,60 & 1,59 & 1,54 & 1,62 & B \\
Kopi & 0,25 & 0,29 & 0,30 & 0,32 & 0,36 & 0,30 & NB \\
Kelapa & 0,10 & 0,10 & 0,10 & 0,10 & 0,12 & 0,10 & NB \\
Coklat & 0,19 & 0,19 & 0,21 & 0,20 & 0,27 & 0,21 & NB \\
Cengkeh & 0,02 & 0,01 & 0,01 & 0,01 & 0,02 & 0,02 & NB \\
Kulit Manis & 0,13 & 0,14 & 0,12 & 0,13 & 0,17 & 0,14 & NB \\
Minyak Nilam & 0,59 & 0,77 & 0,34 & 0,47 & 0,39 & 0,51 & NB \\
Kemiri & 0,41 & 0,42 & 0,40 & 0,42 & 0,51 & 0,43 & NB \\
Tembakau & 0,01 & 0,02 & 0,04 & 0,03 & 0,01 & 0,02 & NB \\
Tebu & 0,02 & 0,01 & 0,01 & 0,01 & 0,01 & 0,01 & NB \\
Pala & 0,00 & 0,00 & 0,00 & 0,00 & 0,01 & 0,00 & NB \\
Lada & 0,00 & 0,00 & 0,00 & 0,00 & 0,01 & 0,00 & NB \\
Kapuk & 0,01 & 0,01 & 0,01 & 0,01 & 0,01 & 0,01 & NB \\
Pinang & 0,14 & 0,26 & 0,28 & 0,27 & 0,18 & 0,23 & NB \\
Panili & 0,07 & 0,06 & 0,08 & 0,15 & 0,19 & 0,11 & NB \\
\hline Sumber : Data & & & & & & &
\end{tabular}

Sumber : Data diolah

Catatan: $\mathrm{NB}=$ Non Basis $\mathrm{B}=$ Basis

Komoditas unggulan perkebunan yang diusahakan di lahan-lahan milik rakyat di Provinsi Sumatera Utara di dalam kajian ini terdiri dari enam belas komoditas unggulan yang paling banyak diusahakan. Berdasarkan hasil analisis LQ pada Tabel 1, menunjukkan bahwa dari 16 komoditas unggulan perkebunan di Provinsi Sumatera yang merupakan komoditas perkebunan basis adalah kelapa sawit dengan nilai LQ sebesar 1,62. Komoditas lainnya seperti karet, kelapa, kopi, coklat, cengkeh, kulit manis, nilam, kemiri, tembakau, tebu, pala, lada, kapuk, pinang, dan panili merupakan komoditas perkebunan non 
basis karena memiliki nilai $\mathrm{LQ}<1$. Dengan demikian sawit merupakan komditas yang selalu berkembang dinamis. Hal ini terjadi karena didukung oleh kondisi wilayah yang snagat cocok untuk dikembangkannya tanaman sawit. Para petani memilih sawit diduga karena penanganannya cukup mudah dengan harga yang bersaing dibanding dengan komoditi yang lain.

\subsection{Analisis Shift Share}

Analisis shift share menjelaskan pengaruh komoditas perkebunan pada wilayah yang lebih tinggi (Indonesia) terhadap komoditas perkebunan daerah Provinsi Sumatera Utara. Pengaruh komponen pertumbuhan produksi (Ni) menunjukkan seberapa besar pertumbuhan komoditas perkebunan di Indonesia berpengaruh (positif atau negatif) terhadap pertumbuhan produksi komoditas perkebunan di Provinsi Sumatera Utara.

Tabel 2. Komponen Shift Share Komoditas Perkebunan di Parovinsi Sumatera Utara tahun 2011-2015

\begin{tabular}{lrrr} 
Komoditas & \multicolumn{1}{c}{$\Delta \mathrm{Ei}$} & \multicolumn{1}{c}{$\mathrm{Ni}$} & \multicolumn{1}{c}{$\Delta \mathrm{Ei}-\mathrm{Ni}$} \\
\hline Perkebunan & $53.476,35$ & $36.301,85$ & $17.174,50$ \\
Karet & $-327.151,05$ & $702.688,17$ & $-1.029 .839,22$ \\
Kelapa Sawit & $11.366,29$ & $6.179,72$ & $5.186,57$ \\
Kopi & $-1.856,89$ & $11.860,89$ & $-13.717,78$ \\
Kelapa & $5.926,52$ & $4.877,88$ & $1.048,64$ \\
Coklat & 267,74 & 48,32 & 219,42 \\
Cengkeh & 328,30 & 481,75 & $-153,45$ \\
Kulit Manis & $-282,11$ & 67,84 & $-349,95$ \\
Minyak Nilam & 802,54 & $1.626,39$ & $-823,85$ \\
Kemiri & 226,34 & 48,50 & 177,84 \\
Tembakau & $-6.088,60$ & $1.173,87$ & $-7.262,47$ \\
Tebu & 24,41 & 3,44 & 20,97 \\
Pala & 79,02 & 11,65 & 67,37 \\
Lada & 42,89 & 14,64 & 28,25 \\
Kapuk & $-984,89$ & 409,93 & $-1.394,82$ \\
Pinang & 42,02 & 7,63 & 34,39 \\
Panili & & & \\
\hline
\end{tabular}

Sumber data: Data sekunder diolah

Tabel 2 di menunjukkan bahwa pada tahun 2011-2015, komponen pertumbuhan komoditas karet, kopi, coklat, cengkeh, tembakau, pala, lada, kapuk dan panili lebih tinggi dibandingkan dengan pertumbuhan komoditas perkebunan nasional sehingga penyimpangan yang terjadi menunjukkan arah yang positif. Komoditas kelapa sawit, kelapa, kulit manis, minyak nilam, kemiri, tebu, dan pinang memiliki komponen pertumbuhan lebih rendah dibandingkan dengan pertumbuhan nasional sehingga dilihat dari penyimpangan yang terjadi menunjukkan arah yang negatif.

Salah satu tujuan dari kajian ini adalah untuk mengetahui komoditas perkebunan strategis dan berpotensi untuk dikembangkan guna memacu pertumbuhan ekonomi dan meningkatkan kesejahteraan petani di Provinsi Sumatera Utara. Untuk mengetahui komoditas perkebunan yang menjadi spesialisasi daerah serta pertumbuhannya digunakan komponen proportional shift (P) dan differential 
shift (D). Untuk itu analisis selanjutnya yaitu analisis untuk mencari komoditas perkebunan yang memiliki pertumbuhan yang cepat atau lambat dan komoditas perkebunan mana yang memiliki daya saing tinggi atau tidak, sehingga digunakan perhitungan terhadap komponen pertumbuhan proporsional dan komponen pertumbuhan diferensial.

Komponen proporsional merupakan suatu alat ukur dalam analisis Shift Share yang menunjukkan perubahan relatif pertumbuhan atau penurunan produktivitas suatu komoditas perkebunan dibandingkan dengan komoditas perkebunan lainnya akibat pengaruh unsur-unsureksternal yang bekerja secara regional. Komoditas perkebunan yang mempunyai nilai $\mathrm{Pi}$ positif berarti komoditi tersebut tumbuh lebih cepat dibandingkan komoditi yang lain sebaliknya jika komoditi tersebut mempunyai $\mathrm{Pi}$ negatif artinya pertumbuhan komoditi tersebut relatif lambat dibandingkan komoditi perkebunan

Tabel 3. Komponen pertumbuhan proporsional (Pi) Komoditas Perkebunan di Provinsi Sumatera Utara tahun 2011-2015

\begin{tabular}{lrr}
\hline Komoditas Perkebunan & \multicolumn{2}{c}{ Priteria } \\
\hline Karet & $-17.203,78$ & Lambat \\
Kelapa Sawit & $451.457,22$ & Cepat \\
Kopi & $-4.932,76$ & Lambat \\
Kelapa & $-17.965,06$ & Lambat \\
Coklat & $-5.655,28$ & Lambat \\
Cengkeh & 218,83 & Cepat \\
Kulit Manis & $-432,29$ & Lambat \\
Minyak Nilam & $-158,21$ & Lambat \\
Kemiri & $-1.474,86$ & Lambat \\
Tembakau & $-69,86$ & Lambat \\
Tebu & 870,48 & Cepat \\
Pala & 16,03 & Cepat \\
Lada & $-10,41$ & Lambat \\
Kapuk & $-37,94$ & Lambat \\
Pinang & $-1.619,34$ & Lambat \\
Panili & $-25,94$ & Lambat \\
\hline
\end{tabular}

Hasil penghitungan pertumbuhan proporsional (Pi) pada tabel 3 di atas menunjukkan komoditas perkebunan yang memiliki nilai $\mathrm{Pi}$ yang positif adalah komoditas kelapa sawit, cengkeh, tebu, dan pala yang berarti bahwa keempat komoditas perkebunan tersebut mempunyai pertumbuhan lebih cepat dibandingkan dengan komoditas lainnya sedangkan komoditas lainnya seperti karet, kopi, kelapa, coklat, kulit manis, minyak nilam, kemiri, tembakau, lada, kapuk, pinang, dan panilli tumbuh lebih lambat.
Komponen

diferensial (Di) digunakan untuk mengetahui daya saing komoditas perkebunan di Provinsi Sumatera Utara. Menurut Tambunan (2001) dalam Lusminah (2013), pertumbuhan pangsa wilayah (differential shift) terjadi karena peningkatan atau penurunan output suatu wilayah yang lebih cepat/lambat dibandingkan wilayahwilayah lain atau nasional yang ditentukan oleh keunggulan komparatif, akses ke pasar input dan output, dukungan kelembagaan, infrastruktur 
sosial dan ekonomi, dan kebijakan ekonomi nasional.

Komoditas perkebunan yang mempunyai nilai Differential Shift (Di) positif menunjukkan bahwa komoditas perkebunan tersebut memiliki daya saing lebih tinggi dibandingkan komoditas perkebunan lainnya di di
Provinsi Sumatera Utara. Sebaliknya komoditas perkebunan yang mempunyai nilai Differential Shift (Di) negatif menunjukkan bahwa komoditas perkebunan tersebut memiliki daya saing lebih rendah dibandingkan komoditas perkebunan lainnya di di Provinsi Sumatera Utara.

Tabel 4. Komponen pertumbuhan differential (Di) Komoditas Perkebunan di Provinsi Sumatera Utara tahun 2011-2015

\begin{tabular}{lrr}
\hline Komoditas Perkebunan & \multicolumn{1}{c}{ Di } & Kriteria \\
\hline Karet & $34.378,28$ & Tinggi \\
Kelapa Sawit & $-1.481 .296,44$ & Rendah \\
Kopi & $10.119,33$ & Tinggi \\
Kelapa & $4.247,28$ & Tinggi \\
Coklat & $6.703,92$ & Tinggi \\
Cengkeh & 0,60 & Tinggi \\
Kulit Manis & 278,84 & Tinggi \\
Minyak Nilam & $-191,75$ & Rendah \\
Kemiri & 651,01 & Tinggi \\
Tembakau & 247,70 & Tinggi \\
Tebu & $-8.132,95$ & Rendah \\
Pala & 4,94 & Tinggi \\
Lada & 77,78 & Tinggi \\
Kapuk & 66,19 & Tinggi \\
Pinang & 224,51 & Tinggi \\
Panili & 60,32 & Tinggi \\
\hline Sunber:
\end{tabular}

Sumber: Data sekunder diolah

Berdasarkan hasil penghitungan differential shift (Di) pada tabel 4 di atas, diketahui bahwa komoditas kelapa sawit dan nilam memiliki nilai Differential Shift yang negatif yang menunjukkan bahwa pertumbuhan komoditas tersebut tumbuh lebih lambat dan memiliki daya saing yang rendah di tingkat nasional. Komoditas perkebunan lainnya seperti karet, kopi, kelapa sawit, coklat,cengkeh, kulit manis, kemiri, tembakau, tebu, pala, lada, kapuk, pinang dan vanili tumbuh lebih cepat dan berdaya saing tinggi di tingkat nasional sehingga komoditas perkebunan tersebut berpotensi untuk dikembangkan dalam memacu pertumbuhan ekonomi dan kesejahteraan petani di Provinsi Sumatera Utara.

\section{SIMPULAN}

Hasil penghitungan LQ menunjukkan bahwa komoditas kelapa sawit merupakan komoditas perkebunan unggulan/basis di Provinsi Sumatera Utara. Analisis Shift share menunjukkan bahwa komoditas karet, kopi, coklat, cengkeh, tembakau, pala, lada, kapuk dan panili mengalami peningkatan pertumbuhan selama peroide 20112015. Komoditas perkebunan yang tumbuh lebih cepat dan memiliki daya saing tinggi adalah karet, kopi, kelapa sawit, coklat,cengkeh, kulit manis, kemiri, tembakau, tebu, pala, lada, kapuk, pinang dan vanili berdasarkan 
analisis differential shift. Pemerintah Provinsi Sumatera Utara perlu menyusun kebijakan yang berkaitan dengan pengembangan sub sektor perkebunan khususnya kebijakan yang dapat memacu pertumbuhan komoditas perkebunan lainnya yang belum menjadi komoditas unggulan/basis sehingga peningkatan kontribusi sub sektor ini dalam pertumbuhan ekonomi dapat tercapai yang memicu peningkatan kesejahteraan petani.

\section{DAFTAR PUSTAKA}

BPS., 2016a. Statistik Indonesia 20112016. Badan Pusat Statistik, Jakarta

BPS., 2016b. Sumatera Utara dalam Angka tahun 2011-2016., Badan Pusat Statistik. Medan

Hidayat Rakhmad. 2013. Analisis Komoditas Unggulan Sub Sektor Perkebunan di Kabupaten Bengkayang Provinsi Kalimantan Barat. Jurnal Social Economic of Agriculture 2: Hal 60

Kristiawan., Hanani-AR N., Soemarno., dan Tyasmoro., S.Y. 2016. Leading product development of fruit using location quotient in Tuban Regency. IOSR Journal of Agriculture and Veterinary Science (IOSR-JAVS) : 9 (8) 8184.

Lusminah. 2008. Analisis Potensi Wilayah Kecamatan Berbasis Komoditi Pertanian Dalam Pembangunan Daerah di Kabupaten Cilacap. Universitas Sebelas Maret. Skripsi

Mira. 2016. Kinerja Sub Sektor Perikanan dan Parawisata Bahari dalam Struktur Perekonomian Wilayah Pesisir. Jurnal Sosek KP : 13-27
Suryani Elrida. 2014. Analisis Sektor Unggulan Kabupaten/Kota di Kawasan MEBIDANGRO Sumatera Utara. Universitas Sumatera Utara. Tesis.

Wahyuningsih T., Hehamahua $H_{\text {., }}$ dan Sahupala A.K.S., 2014. Determination of agricultural sectors and subsectors potentially leading and with superior in district Hie location quotient method static, dynamic input, and output location quotient. Journal of Economic and Sustainable Development : 5 (28) 72-81. 